\title{
Reformasi Hukum Tanah dalam Rangka Perlindungan Hak Atas Tanah Perorangan dan Penanam Modal dalam Bidang Agrobisnis
}

\author{
Darwin Ginting \\ Sekplah Tinggi Hukum Bandung \\ Jl. Cihampelas No. 8 Bandung \\ dr.darwinginting_sh@yahoo.co.id
}

\begin{abstract}
The problem which would be discussed is how the policy format of law in the future mentioned the rights protection on individual land property and investment in agribusiness field. This research is juridical normative research using statutory approach. Data processing and analysis which was performed is descriptive qualitative. The result of the research concluded that; first, it is necessary to form regulation of land property rights, so that it could support the certainty of land property rights for individual and the certainty of law for every sector of capital investment. Second, the formation of the legislation prioritized the citizen's aspiration and the community of agribusiness industrial field.
\end{abstract}

Key words : Reformation, land titles, private and agribusiness

\begin{abstract}
Abstrak
Penelitian ini mengkaji format kebijakan hukum masa depan yang mengungkap perlindungan hak atas tanah perorangan dan penanaman modal di bidang agrobisnis. Penelitian ini adalah penelitian hukum normatif dengan metode pendekatan perundang-undangan (statute approach). Pengolahan dan analisis data yang digunakan adalah deskriptif kualitatif. Hasil penelitian menyimpulkan bahwa pertama, perlu segera dilakukan pembentukan rancangan undang-undang hak atas tanah, sehingga dapat menunjang kepastian hak atas tanah bagi perorangan dan kepastian hukum bagi setiap sektor penanaman modal, lebih khususnya bidang agrobisnis; kedua, pembentukan perundang-undangan tersebut mengedepankan aspirasi masyarakat dan masyarakat industri bidang agrobisnis.
\end{abstract}

Kata kunci : Reformasi, hak atas tanah, perorangan dan agribisnis. 


\section{Pendahuluan}

Sebelum membahas secara detail dan komprehensif mengenai reformasi hukum tanah dalam rangka perlindungan hak atas tanah perorangan dan penanaman modal (investor), maka terlebih dahulu diuraikan mengenai istilah reformasi, dengan maksud agar tidak terjadi salah pengertian tentang reformasi itu. Istilah reformasi mulai dikenal oleh masyarakat Indonesia sejak tumbangnya Presiden Soeharto pada 20 Mei 1998 dari kursi pemerintahannya. Kata reformasi ${ }^{1}$ itu sendiri dikenal dalam berbagai bahasa, seperti kata reforme dalam bahasa Perancis yang berarti perubahan atau pembaharuan. ${ }^{2}$ Dalam bahasa Spanyol dengan istilah reforma yang berarti perbaikan atau pembaharuan. ${ }^{3}$ Di dalam bahasa Belanda terdapat kata reformatie yang berarti reformasi, ${ }^{4}$ yang juga dijumpai dalam bahasa Inggris dengan kata reformation, ${ }^{5}$ sama pengertian dalam bahasa Belanda yang berarti reformasi. Dalam Kamus Besar Bahasa Indonesia disebutkan bahwa kata reformasi diartikan sebagai perubahan radikal untuk perbaikan (bidang sosial, politik, atau agama) di suatu masyarakat atau negara. ${ }^{6}$

Reformasi hukum itu sendiri adalah upaya-upaya perubahan secara radikal sistem hukum, yang didalamnya terdapat : Pertama, cara berpikir terhadap hukum yang selama ini masih dipengaruhi oleh ajaran Austin dan aliran Kelsenian tentang bahwa hukum atau secara positif dan tertulis disebut undang-undang adalah sebagai a command of the lawgiver (perintah dari pembentuk undang-undang atau penguasa). ${ }^{7}$ Kedua, proses penyusunan peraturan perundang-undangan yang tidak melihat permasalahan - yang harus dipecahkan melalui hukum - secara komprehensif dan multisektor (lintas sektoral), sehingga menghasilkan peraturan perundangundangan yang tertatih-tatih mengikuti perkembangan masyarakat (henk in achter

\footnotetext{
${ }^{1}$ Kata "reformasi" mulai populer di Eropa sejak Martin Luther mengkampanyekan gagasannya tentang protestanisme. Gagasan Luther ini menginginkan reformasi teologi Katolik Roma yang berkembang di eropa sejak abad klasik dan pertengahan. Lihat: Michael Lewi, Teologi Pembebasan, Yogyakarta, Insist Press bekerjasama dengan Pustaka Pelajar, Cet. II, 2000, hlm. 66

${ }^{2}$ Winarsih Arifin \& Farida Soemargono, Kamus Perancis Indonesia; Dictionnaire Francais - Indonesien, Gramedia Pustaka Utama, Jakarta, 2007, hlm. 888

${ }^{3}$ Milagros Guindel, Kamus Spanyol Indonesia, Gramedia Pustaka Utama, Jakarta, 2001, hlm. 604

${ }^{4}$ Susi Moeimam \& Hein Steinhauer, Kamus Belanda - Indonesia, Jakarta, Gramedia Pustaka Utama, 2008, hlm. 851

${ }^{5}$ John M. Echols \& Hassan Shadily, Kamus Inggris - Indonesia; An English - Indonesian Dictionary, Itacha and Cornell University Press - Gramedia, London - Jakarta, 1995, hlm 473

${ }^{6}$ Tim Penyusun Kamus Pusat Pembinaan dan Pengembangan Bahasa, Op. Cit. hlm. 826

${ }^{7}$ John Austin sebagaimana dikutip oleh : Shidarta, Karakteristik Penalaran Hukum Dalam Konteks Keindonesiaan, CV. Utomo, Bandung, 2006, hlm. 252. Lihat pula : Lili Rasjidi \& Ira Thania Rasjidi, Pengantar Filsafat Hukum, Mandar Maju, Bandung, 2002, hlm. 56
} 
de feiten aan). Ketiga, harmonisasi antar peraturan hukum yang belum bersimbiosis mutualisme, sehingga terdapat satu undang-undang yang arahnya ke utara dan undang-undang lainnya ke selatan. Bertitik tolak dari conflik of norm (perseteruan norma) akibat disharmonisasi ini terjadi pula antara UUPA dengan Undang-Undang Penanaman Modal. Keempat, lembaga atau institusi pemerintahan yang berwenang dalam sesuatu bidang yang terkadang tumpang tindih (overlapping) dengan institusi lainnya. Akibatnya adalah terhadap lembaga mana yang berwenang membentuk hukum dan lembaga mana yang berwenang untuk menerapkan hukum.

Joyo Winoto menggunakan istilah "reforma" seperti dalam istilah Spanyol "reforma" untuk sinonim dari kata pembaharuan. Sebagaimana dalam naskah pidato yang disampaikan dalam rangkaian Dies Natalis Universitas Padjadjaran ke-50 di Bandung Tanggal 10 September 2007 yang berjudul “Reforma Agraria dan Keadilan Sosial". Dalam pidatonya mengatakan bahwa reforma agraria merupakan jawaban yang muncul terhadap masalah ketimpangan struktur agraria, kemiskinan dan ketahanan pangan dan pembangunan wilayah. Memetik pengalaman dari berbagai negara, reforma agraria secara garis besar dapat dikelompokkan menjadi 4 (empat) kategori: ${ }^{8}$ Pertama: radical land reform, tanah milik tuan tanah perkebunan luas diambil alih oleh pemerintah tanpa ganti kerugian, dan selanjutnya dibagikan kepada petani tidak bertanah; Kedua: land restution, tanah-tanah perkebunan luas yang berasal dari tanah-tanah masyarakat diambil alih oleh pemerintah, kemudian tanah tersebut dikembalikan kepada pemilik asal dengan konpensasi; Ketiga: land colonization, pembukaan dan pengembangan daerah-daerah baru, kemudian penduduk dari daerah yang pada penduduknya dipindahkan ke daerah baru tersebut, dan dibagikan tanah dengan luasan tertentu; dan keempat: market based land reform (market assisted land reform), land reform yang dilaksanakan berdasarkan atau dengan bantuan mekanisme pasar yang bisa berlangsung bila tanah-tanah diberikan hak (land titling) agar security in tenureship bekerja untuk mendorong pasar finansial di pedesaan. Model-model ini umumnya tidak bisa memenuhi prinsip land reform untuk melakukan penataan penguasaan dan pemilikan tanah yang adil.

Mendesaknya reformasi pertanahan saat ini menurut Joyo Winoto ${ }^{9}$ sangat $^{-}$ didasarkan pada data kemiskinan terakhir BPS yang menunjukkan bahwa jumlah

${ }^{8}$ Joyo Winoto, Reforma Agraria dan Keadilan Sosial, Bandung, Pidato Ilmiah yang disampaikan dalam rangkaian Dies Natalis Universitas Padjadjaran ke-50 tanggal 10 September 2007, hlm. 13

${ }^{9}$ Ibid., hlm. 3 
orang miskin di Indonesia mencapai 37.170.000 jiwa atau 16,58\% dari total populasi Indonesia. Di kawasan perkotaan, percepatan kemiskinan tersebut adalah 13,36\%, sedangkan di kawasan pedesaan mencapai 21,9\%. Ini menunjukkan bahwa kemiskinan paling banyak dialami penduduk pedesaan yang pada umumnya adalah petani. Dari total rakyat miskin di Indonesia, sekitar 66\% berada di pedesaan dan sekitar 56\% menggantungkan hidupnya dari pertanian. Seluruh penduduk miskin pedesaan ini ternyata sekitar 90 persen bekerja keras, tetapi tetap miskin. Hal ini terutama disebabkan oleh lemahnya akses masyarakat terhadap sumbersumber ekonomi dan sumber-sumber politik termasuk yang terutama adalah tanah. Keseluruhan kehidupan di pedesaan ternyata memiliki percepatan yang lebih tinggi daripada perkotaan. Hal ini menandakan pentingnya kita menata kembali kehidupan di pedesaan, dalam konteks keadilan dan pemerataan.

Apa yang dikemukakan Joyo Winoto di atas, sejalan dengan fakta yang dipaparkan dalam RPJMN bahwa berdasarkan hasil Sensus Pertanian, jumlah petani dalam kurun waktu 1983-2003 meningkat namun dengan jumlah lahan pertanian menurun, sehingga rata-rata pemilikan lahan per petani menyempit dari 1,30 ha menjadi 0,2 ha per petani. Melalui luasan lahan usaha tani seperti ini, meskipun produktivitas per luas lahan cukup tinggi, namun tidak dapat memberikan pendapatan petani yang cukup untuk menghidupi rumah tangga dan pengembangan usaha para petani. Hal ini merupakan tantangan besar dalam rangka mengamankan produksi padi / beras dari dalam negeri untuk mendukung ketahanan pangan nasional termasuk di dalamnya sektor agrobisnis dan peningkatan daya saing komoditas pertanian. Hal ini sangat berbeda dengan apa yang diterapkan di negara Malaysia, Thailand dan Taiwan karena ditentukan secara limitatif batas minimum untuk lahan pertanian. ${ }^{10}$

Menghadapi fakta-fakta di atas, dapat menimbulkan pertanyaan, apakah kenyataan tersebut berdiri sendiri tanpa sebab dari segala aspek, termasuk aspek hukum?. Pada kenyataannya hukum juga memberi kontribusi yang besar terhadap munculnya ketimpangan struktur penguasaan lahan bagi petani di pedesaan, dan munculnya kemiskinan bagi petani di perdesaan. Antara lain mengenai hak-hak atas tanah, yang masih belum ada sinkronisasi satu sama lain, baik sinkronisasi vertikal maupun sinkronisasi horisontal. Antara UUD 1945 dan UUPA dan antara

${ }^{10}$ Suparji, Penanaman Modal Asing di Indonesia, Insentif V. Pembatasan, Universitas Al-Azhar Indonesia, Jakarta, 2008, hlm. 302. 
UUPA dan undang-undang yang menyangkut tanah lainnya berserta peraturan pelaksanaanya. Antara UUPA dan undang-undang sektoral lainnya, seperti antara UUPA dengan Undang-Undang Nomor 25 Tahun 2007 Tentang Penanaman Modal khususnya dibidang jangka waktu hak-hak atas tanah.

\section{Rumusan Masalah}

Dari uraian di atas, dirumuskan masalah yang akan diteliti adalah bagaimana format kebijakan hukum masa depan yang mengungkap perlindungan hak atas tanah perorangan dan penanaman modal bidang agrobisnis?

\section{Tujuan Penelitian}

Penelitian ini bertujuan untuk menemukan format kebijakan hukum masa depan yang mengungkap perlindungan hak atas tanah perorangan dan penanaman modal bidang agrobisnis.

\section{Metode Penelitian}

Penelitian ini adalah penelitian hukum normatif dengan metode pendekatan perundang-undangan (statute approach). ${ }^{11}$ Pendekatan perundang-undangan (statute approach) dilakukan dengan mempelajari dasar ontologis lahirnya peraturan perundang-undangan, landasan filosofis peraturan perundang-undangan.

Penelitian ini mempergunakan bahan hukum primer (primary sources or authorities) dan bahan hukum sekunder (secondary sources or authorities). ${ }^{12}$ Penelitian kepustakaan (library research) dilakukan untuk memperoleh: Pertama, bahan hukum primer yang berupa aturan dasar dan peraturan perundang-undangan yang mengatur tentang hukum tanah dan penanaman modal. Melalui bahan-bahan hukum inilah diharapkan akan ditemukan format kebijakan hukum masa depan yang mengungkap perlindungan hak atas tanah perorangan dan penanaman modal bidang agribisnis.

${ }^{11}$ Peter Mahmud Marzuki, Penelitian Hukum, Cetakan Ke-2, Kencana Prenada Media Group, Jakarta, 2006, hlm. 102. Lihat juga Johnny Ibrahim, Teori \& Metodologi Penelitian Hukum Normatif, Cetakan Kedua, Bayumedia Publishing, Malang, 2006, hlm. 302-303.

${ }^{12}$ Sunaryati Hartono, Penelitian Hukum di Indonesia Pada Akbir Abad ke-20, Alumni, Bandung, 1994, hlm. 134, 151. 
Kedua, bahan hukum sekunder, yaitu yang memberikan penjelasan mengenai bahan hukum primer, seperti: hasil-hasil penelitian terdahulu, karya ilmiah dari kalangan ahli hukum dan non hukum yang relevan dengan obyek penelitian ini, risalah persidangan pembentukan undang-undang; dan ketiga, bahan hukum tersier yang memberikan petunjuk maupun penjelasan terhadap bahan hukum primer dan sekunder, berupa kamus dan ensiklopedi. ${ }^{13}$

Pengolahan dan analisis data yang digunakan adalah diskriptif kualitatif. Pengolahan data pada hakikatnya merupakan kegiatan untuk mengadakan sistematisasi terhadap bahan-bahan hukum. Sistematisasi berarti membuat klasifikasi terhadap bahan-bahan hukum tersebut untuk memudahkan pekerjaan analisis dan konstruksi. ${ }^{14}$

\section{Hasil dan Pembahasan}

Membedah pembangunan hukum agraria nasional, secara teoritik tidak dapat dipisahkan dari teori hukum pembangunan yang telah dikemukakan oleh Kusumaatmadja. Pendekatan ini merupakan pendekatan ilmu hukum sebagai ilmu (scientific legal approach) dan sekaligus sebagai pendekatan filsafat hukum (philosophical legal approach) yang menjadi "bintang pemandu" dan dapat memverifikasi pentingnya paradigma baru pembangunan hukum agraria nasional. Menurut Kusumaatmadja,"15 hukum harus berfungsi sebagai sarana pembaruan masyarakat" Teori hukum pembangunan ini oleh Rasjidi" sebagai berikut “Teori hukum pembangunan Kusumaatmadja, kemudian lebih merupakan transformasi dari teori hukumnya sendiri, ditambah dengan transformasi dari teori hukum Roescoe Pound. Tetapi hal yang sangat penting harus diberi perhatian lebih adalah mentransformasi teori hukum Pound. Kusumaatmadja dengan sangat ketat menyatakan bahwa ia menolak konsepsi mekanis dari konsepsi "law as a tool of social engineering", dan karenanya menggantikan istilah alat (a tool) itu dengan istilah sarana".

Hakikat dari teori hukum pembangunan adalah bahwa penggunaan kata "alat" terkesan mekanistik, sedangkan hukum harus melihat objek yang diatur, yakni

\footnotetext{
${ }^{13}$ Soerjono Soekanto dan Sri Mamudji, Penelitian Hukum Normatif, RajaGrafindo Persada, Jakarta, 1995, hlm. 29.

${ }^{14}$ Soerjono Soekanto, Pengantar Penelitian Hukum, UI Press, Jakarta, 1986, hlm. 251-252.

${ }^{15}$ Kusumaatmadja M, Konsep-konsep Hukum dalam pembangunan. Pusat Studi Wawasan Nusantara, Hukum dan Pembangunan Bekerjasama dengan Alumni, Bandung, 2002, hlm 14.

${ }^{16}$ Rasjidi L \& I.B.W. Putra, Hukum sebagai suatu sistem, Mandar Maju, Bandung, 2003, hlm 183.
} 
manusia (secara natural) bukan benda mati. Justru itu digunakan istilah "sarana" dalam rangka memperbaharui masyarakat.

Untuk mendukung bekerjanya teori hukum pembangunan, maka digunakan konsep-konsep dasar politik hukum (rechtspolitiek theorien) yang dalam referensi anglosaxis dikenal dengan teori Kebijakan Hukum (Legal Policy Theory). ${ }^{17}$ Menurut Budi Harsono, 18 "Politik hukum berfungsi untuk menciptakan sistem hukum nasional yang dikehendaki dengan titik berat pada dimensi hukum yang dicitacitakan (ius constituendum)". Sehingga dapat dikatakan bahwa politik hukum adalah bagian dari kajian hukum karena membicarakan perencanaan hukum (legal planning) dan perencanaan hukum (legal Drafting), yang bersubstansi pada bagaimana hukum itu dikondisikan, konkordinasi hukum, penghalusan hukum, plrurualisme hukum, unifikasi hukum dan lain-lain. Oleh sebab itu, politik hukum yang terkait erat dengan upaya-upaya pembaharuan hukum adalah bagian menata tata hukum yang ada, sehingga menunjang tercapainnya harmonisasi perundang-undangan termasuk di dalamnya UUPA dengan Undang-Undang Nomor 25 Tahun 2007.

Upaya-upaya ke dalam reformasi hukum tanah di Indonesia sebenarnya telah ada semenjak lahirnya UUPA namun masih ketinggalan dengan perkembangan kebutuhan masyarakat yang dinamis, sehingga belum terwujud dalam bentuk norma hukum positif (ius constitutum), namun reformasi terhadap hukum pertanahan tetap berlanjut dengan mengeluarkan instrumen-instrumen peraturan perundangundangan yang berhubungan dengan UUPA. Namun pelaksanaan reformasi terhadap UUPA atau khususnya hukum tanah terdapat pasang surut baik didalam pemerintahan Orde Lama maupun pemerintahan Orde Baru. Setelah Orde Baru jatuh khusus mengenai pembaharuan UUPA dikeluarkan ketetapan Majelis Permusyawaratan Rakyat Nomor IX Tahun 2001 tentang Pembaharuan Agraria dan Pengelolaan Sumber Daya Alam. Beberapa alasan mendasar berkaitan dengan terbitnya ketetapan MPR ini antara lain sebagai berikut: ${ }^{19} 1$. Sumber daya agraria/sumber daya alam meliputi bumi, air, ruang angkasa dan kekayaan alam yang terkandung di dalamnya sebagai rahmat Tuhan Yang Maha Esa kepada bangsa Indonesia merupakan kekayaan nasional yang wajib disyukuri. Oleh karena itu, harus dikelola dan dimanfaatkan secara optimal bagi generasi sekarang dan generasi mendatang dalam

\footnotetext{
${ }^{17}$ Syaukani I \& Thohari A.A, Dasar-dasar Politik. Hukum, Raja Grafindo Persada, Jakarta, 2004.

${ }^{18}$ Budi Harsono, Reformasi Hukum Tanah Yang Berpihak Kepada Rakyat, Mandar Maju, Bandung, 1991, hlm.1.

${ }^{19}$ Ketetapan Majelis Permusyawaratan Rakyat Tentang Pembaharuan Agraria dan Pengelolaan Sumber Daya Alam Nomor IX Tahun 2001,
} 
rangka mewujudkan masyarakat adil dan makmur; 2. MPR mempunyai tugas konstitusional untuk menetapkan arah dan dasar bagi pembangunan nasional yang dapat menjawab berbagai persoalan kemiskinan, ketimpangan, dan ketidakadilan sosial ekonomi rakyat, serta kerusakan sumber daya alam; 3. Pengelolaan sumber daya agraria/sumber daya alam yang berlangsung selama ini telah menimbulkan penurunan kualitas lingkungan, ketimpangan struktur penguasaan, pemilikan, penggunaan dan pemanfaatannya serta menimbulkan berbagai konflik; 4. Peraturan perundang-undangan yang berkaitan dengan pengelolaan sumber daya agraria/ sumber daya alam saling tumpang tindih dan bertentangan; 5. Pengelolaan sumber daya agraria/sumber daya alam yang adil, berkelanjutan dan ramah lingkungan harus dilakukan dengan cara terkoordinasi, terpadu dan menampung dinamika, aspirasi dan peran serta masyarakat, serta menyelesaikan konflik; 6. Untuk mewujudkan cita-cita luhur bangsa Indonesia sebagaimana tertuang dalam pembukaan Undang-Undang Dasar Negara Republik Indonesia Tahun 1945, diperlukan komitmen politik yang sungguh-sungguh untuk memberikan dasar dan arah bagi pembaharuan agraria dan pengelolaan sumber daya alam yang adil, berkelanjutan dan ramah lingkungan.

Demi menjamin terwujudnya idealisme tersebut pembaharuan agraria dan pengelolaan sumber daya alam harus dilaksanakan prinsip-prinsip antara lain: ${ }^{20} 1$. memelihara dan mempertahankan keutuhan Negara Kesatuan Republik Indonesia; 2. menghormati dan menjunjung tinggi hak asasi manusia; 3 . menghormati supremasi hukum dengan mengakomodasi keanekaragaman dalam unifikasi hukum; 4. mensejahterakan rakyat, terutama melalui peningkatan kualitas sumber daya manusia Indonesia; 5. mengembangkan demokrasi, kepatuhan hukum, transparansi, dan optimalisasi partisipasi masyarakat; 6. mewujudkan keadilan termasuk kesetaraan gender dalam penguasaan, pemilikan, penggunaan, pemanfaatan dan pemeliharaan sumber daya agraria/sumber daya alam; 7. memelihara keberlanjutan yang dapat memberi manfaat yang optimal, baik untuk generasi sekarang maupun generasi mendatang, dengan tetap memperhatikan daya tampung dan daya dukung lingkungan; 8. melaksanakan fungsi sosial, kelestarian, dan fungsi ekologis sesuai dengan kondisi sosial budaya setempat; 9. meningkatkan keterpaduan dan koordinasi antarsektor pembangunan dan antardaerah dalam pelaksanaan pembaruan dan pengelolaan sumber daya agraria; 10. mengakui, menghormati, dan

${ }^{20}$ Ibid., Pasal 4. 
melindungi hak masyarakat hukum adat dan keagamaan budaya bangsa atas sumber daya agraria/sumber daya alam; 11. mengupayakan keseimbangan hak dan kewajiban negara, pemerintah (pusat, daerah provinsi, kabupaten/kota, dan desa atau yang setingkat), masyarakat dan individu; 12. melaksanakan desentralisasi berupa pembagian kewenangan di tingkat nasional, daerah provinsi, kabupaten/ kota, dan desa atau yang setingkat, berkaitan dengan alokasi dan pengelolaan sumber daya agraria/sumber daya alam.

Sebagai bidang yang menyangkut kehidupan orang banyak perlu adanya arah kebijakan pembaharuan agraria yang meliputi antara lain: 1. melakukan pengkajian ulang terhadap berbagai peraturan perundang-undangan yang berkaitan dengan agraria dalam rangka sinkronisasi kebijakan antarsektor; 2. melaksanakan penataan kembali penguasaan, pemilikan, penggunaan, pemanfaatan tanah yang berkeadilan dengan memperhatikan kepemilikan tanah untuk rakyat; 3. menyelenggarakan pendataan pertanahan melalui inventarisasi dan registrasi penguasaan, pemilikan, penggunaan, pemanfaatan tanah secara komprehensif dan sistematis dalam rangka pelaksanaan landreform; 4. menyelesaikan konflik-konflik yang berkenaan dengan sumber daya agraria yang timbul sekaligus dapat mengantisipasi timbulnya konflik baru; 5. memperkuat kelembagaan dan kewenangannya dalam rangka mengemban pelaksanaan pembaharuan agraria dan menyelesaikan konflik-konflik yang berkenaan dengan sumber daya agraria; 6. mengupayakan dengan sungguh-sungguh pembiayaan dalam melaksanakan program pembaharuan agraria.

Di samping itu arah kebijakan pengelolaan sumber daya alam ditekankan antara lain : 1. melakukan pengkajian ulang terhadap berbagai peraturan perundangundangan yang berkaitan dengan pengelolaan sumber daya alam dalam rangka sinkronisasi kebijakan antarsektor; 2. mewujudkan optimalisasi pemanfaatan berbagai sumber daya alam melalui identifikasi dan inventarisasi kualitas dan kuantitas sumber daya alam; 3. memperluas pemberian akses informasi kepada masyarakat mengenai potensi sumber daya alam di daerahnya dan mendorong terwujudnya tanggungjawab sosial untuk menggunakan teknologi ramah lingkungan termasuk teknologi tradisional; 4. memperhatikan sifat dan karakteristik dari berbagai jenis sumber daya alam dan melakukan upaya-upaya meningkatkan nilai tambah dari produk sumber daya alam; 5. menyelesaikan konflik-konflik pemanfaatan sumber daya alam yang timbul selama ini sekaligus mengantisipasi potensi konflik dimasa mendatang; 6. mengupayakan pemulihan ekosistim yang 
telah rusak akibat eksploitasi sumber daya alam secara berlebihan; 7. menyusun strategi pemanfaatan sumber daya alam yang didasarkan kepada optimalisasi manfaat dengan memperhatikan potensi, kontribusi, kepentingan masyarakat dan kondisi daerah maupun nasional.

Dari ketetapan Majelis Permusyawaratan Rakyat ini terlihat ke arah mana pembaharuan UUPA dan sumber daya alam harus direalisasikan. Untuk melaksanakan ketetapan MPR, Majelis Permusyawaratan Rakyat mengingatkan kembali perlunya reformasi agraria dengan dikeluarkannya keputusan MPR nomor 5 Tahun 2003 dan untuk menindaklanjuti, maka pemerintah mengeluarkan Keputusan Presiden Nomor 34 Tahun 2003 Tentang Kebijakan Nasional di bidang Pertanahan yang intinya menekankan langkah-langkah yang harus dilakukan antara lain $:^{21} 1$. penyusunan rancangan undang-undang penyempurnaan undang-undang Nomor 5 tahun 1960 Tentang Peraturan Dasar Pokok-Pokok Agraria dan rancangan undang-undang Tentang Hak Atas Tanah serta peraturan perundang-undangan lainnya di bidang pertanahan; 2. pembangunan sistem informasi dan manajemen pertanahan yang meliputi : a) penyusunan basis data tanah, tanah asset negara/daerah; b) penyiapan aplikasi data tekstual dan spasial dalam pelayanan pendaftaran tanah dan penyusunan basis data penguasaan dan pemilikan tanah; c) pemetaan kadestral dalam rangka inventarisasi dan registrasi penguasaan, pemilikan, penggunaan, dan pemanfaatan tanah dengan menggunakan teknologi citra satelit dan teknologi informasi untuk menunjang kebijakan pelaksanaan landreform dan pemberian hak atas tanah; d) pembangunan dan pengembangan pengelolaan penggunaan dan pemanfaatan tanah melalui sistem informasi geografi dengan mengutamakan penetapan zona sawah beririgasi dalam rangka memelihara ketahanan pangan nasional.

Untuk mewujudkan tujuan kebijakan pertanahan tersebut perlu dilakukan langkah-langkah sebagai berikut:22 1 . reformasi peraturan perundang-undangan yang menyangkut pertanahan, mengembangkan dan menetapkan undang-undang pokok yang memayungi keseluruhan peraturan perundang-undangan sektoral lainnya, sinkronisasi seluruh peraturan perundang-undangan yang terkait dengan pertanahan, revisi seluruh peraturan perundang-undangan pertanahan yang tidak sesuai dengan prinsip-prinsip yang terkandung pada Pasal 33 ayat (3) UUD 1945; 2. pengembangan kelembagaan pertanahan, menentukan kewenangan bidang

\footnotetext{
${ }^{21}$ Keputusan Presiden Tentang Kebijakan Nasional Dibidang Pertanahan Nomor 34 Tahun 2003 Pasal 1.

${ }^{22}$ Ibid., hlm. VI
} 
pertanahan antar sektor dan tingkat pemerintah, menentukan struktur kelembagaan pertanahan dan memperkuat kelembagaan pertanahan sesuai tugas dan fungsinya; 3. meningkatkan pengelolaan pendaftaran tanah dan percepatannya; 4 . mengembangkan penatagunaan tanah secara kompreshensif sesuai dengan karakteristik dan daya dukung lingkungannya dengan menerapkan prinsip good governance (transparasi, partisipasi dan akuntabel); 5. mengembangkan sistem informasi berbasis tanah dengan menentukan dan mengembangkan standard sistem informasi tanah; 6. penyelesaikan sengketa tanah secara konfrenhensif; 7. mengembangkan sistem perpajakan tanah sebagai salah-satu instrumen dalam distribusi asset tanah yang berkeadilan; 8. perlindungan hak-hak masyarakat atas tanah; 9. peningkatan akses dan asset tanah terhadap seluruh masyarakat.

Untuk melaksanakan perintah ketetapan Majelis Permusyawaratan Rakyat Nomor IX Tahun 2001 dan Keputusan Presiden Nomor 34 Tahun 2003 telah dilakukan gagasan-gagasan ke arah reformasi hukum tanah nasional atau UUPA, baik yang digaungkan oleh para akademisi hukum tanah, maupun oleh para politisi, termasuk para birokrasi pertanahan di Badan Pertanahan Nasional (BPN) dalam bentuk antara lain Naskah Akademis (academic draft) rancangan undang-undang hak tanah. Sebagaimana diketahui bahwa upaya-upaya reformasi hukum agraria nasional sesungguhnya pernah digagas di Badan Pertanahan Nasional (BPN), dalam bentuk rencana revisi terhadap UUPA yang drafnya telah dilakukan uji publik kebeberapa kota besar di Indonesia, namun belum terrealisasi. Dari hasil penelitian, peneliti belum menemukan jawaban yang jelas, sehingga upaya amandemen terhadap UUPA belum dapat diteruskan (dalam rangka untuk disesuaikan dengan perkembangan masyarakat sekarang ini). Sehingga perlu segera dipikirkan untuk membentuk Rancangan Undang-Undang (RUU) tentang Hak Atas Tanah yang berfungsi sebagai lex spesialist dari UUPA. Hal ini perlu dikaji ulang dalam rangka memberikan perlindungan hak-hak atas tanah baik secara perorangan maupun dalam rangka penanaman modal bidang agrobisnis. Diharapkan melalui rancangan undangundang ini mengatur secara komprehensif bagaimana menata asset dan akses masyarakat terhadap tanah, termasuk didalamnya mengatur status tanah, penyederhanaan hak atas tanah, pengakuan hak ulayat dan perlindungan terhadap tanah-tanah yang produktif, misalnya tanah sawah yang subur beririgasi.

Dalam upaya membuat Rancangan Undang-Undang tentang Hak Tanah perlu dicermati pengaturan hak atas tanah baik sebagian lembaga hukum maupun ditinjau 
dari aspek hubungan hukum konkrit, ditemukan berbagai hambatan terutama terkait dengan permasalahan regulasi, yaitu antara lain:

\section{Inkonsistensi Regulasi Pertanahan}

Akibat dari peraturan hak tanah yang terpisah-pisah dalam berbagai bentuk peraturan perundang-undangan, maka terjadi inkonsistensi (ketidakkonsistenan) atau bahkan cenderung mengarah pada ketidaksinkronan antara satu dengan yang lainnya. Hal ini tampak dalam penentuan jangka waktu hak, tata cara penetapan serta kewajiban-kewajiban dari pemegang hak tanah maupun jenis hak untuk keperluan tertentu. Pengaturan jangka waktu hak atas tanah terdapat perbedaan dan benturan hierarki peraturan perundang-undangan antara ketentuan yang tercantum dalam UUPA dan Peraturan Pemerintah Nomor 40 Tahun 1996. Demikian juga yang diatur dalam Undang-Undang Nomor 25 Tahun 2007.

Berkaitan dengan tata cara penetapan hak terdapat dalam berbagai bentuk tanah melalui proses pemberian hak secara umum, individual maupun kolektif, pemberian hak secara massal maupun perorangan serta penetapan hak melalui lembaga penegasan hak, pengakuan hak serta pemberian hak tanah. Perbedaanperbedaan tata cara penetapan hak juga terjadi berkaitan dengan kegiatan redistribusi tanah, pendaftaran tanah secara sistematis, pemberian hak dalam rangka transmigrasi, konsolidasi tanah dan sebagainya. Terdapat istilah-istilah yang tidak ditemukan pada UUPA namun berkembang di praktek birokrasi, misalnya istilah "pembaharuan hak" dan "peningkatan hak" atau "penurunan hak". ${ }^{23}$

Inkonsistensi terjadi juga pada pelaksanaan pembatalan hak. Hal ini terlihat dalam hal tenggang waktu kewenangan pembatalan dimaksud. Sebagai contoh pembatalan hak tanah yang diatur Peraturan Pemerintah Nomor 24 Tahun 1997 dan Peraturan Menteri Negara Agraria/Kepala Badan Pertanahan Nasional Nomor 9 Tahun 1999. Pasal 14 Peraturan Menteri Negara Agraria/Kepala Badan Pertanahan Nasional Nomor 9 Tahun 1999 menentukan bahwa pembatalan hak karena cacat hukum administrasi dalam penetapannya, dapat dilakukan berdasarkan atau tidak berdasarkan permohonan yang berkepentingan tanpa melalui proses pengadilan. Pembatalan hak tanah tersebut dilakukan dengan keputusan menteri.

\footnotetext{
${ }^{23}$ Darwin Ginting, Kepastian Hukum Kepemilikan Hak, Atas Tanah Bidang Agribisnis di Indonesia, Unpad Press, Bandung, 2009, hlm. 112.
} 
Pelaksanaan ketentuan tersebut berbenturan dengan Pasal 32 ayat (2) Peraturan Pemerintah Nomor 24 Tahun 1997, yang menentukan bahwa dalam hal suatu bidang tanah sudah diterbitkan sertifikat secara sah atas nama orang atau badan hukum yang memperoleh tanah tersebut dengan itikad baik dan secara nyata menguasainya, maka pihak lain yang merasa mempunyai tanah itu tidak dapat lagi menuntut pelaksanaan hak tersebut apabila dalam kurun waktu 5 (lima) tahun sejak diterbitkan sertifikat itu atau tidak dapat mengajukan keberatan kepada pemegang sertifikat atau kepada Kepala Kantor Pertanahan yang bersangkutan atau mengajukan ke Pengadilan mengenai pengawasan tanah atau penerbit sertifikat tersebut. Hal ini berarti apabila suatu bidang tanah telah didaftar dengan diterbitkan sertifikat hak atas tanahnya, maka sejak 5 (lima) tahun setelah diterbitkan sertifikat dimaksud, maka pihak lain yang merasa mempunyai tanah gugur haknya untuk melakukan upaya hukum atas tanah tersebut.

Semangat yang diatur dalam Pasal 32 ayat (2) Peraturan Pemerintah Nomor 24 Tahun 1997 mempunyai nilai positif dalam rangka meningkatkan atau memperbesar kekuatan pemegang sertifikat, sehingga sekaligus mendorong terwujudnya kepastian hukum bagi pemegang hak atas tanah tersebut. Lebih jauh apa yang diatur dalam norma Pasal 32 ayat (2) Peraturan Pemerintah Nomor 24 Tahun 1997 mempunyai relevansi yang signifikan untuk terwujudnya sistem pendaftaran tanah yang negatif cenderung ke positif.

Idealnya, tuntutan pembatalan hak sudah tidak dimungkinkan lagi dilakukan dimasa-masa yang akan datang. Pelaksanaan ketentuan Pasal 32 ayat (2) Peraturan Pemerintah Nomor 24 Tahun 1997 tersebut yang mengatur tentang tenggang waktu di mana suatu hak tanah setelah terdaftar sejak 5 (lima) tahun tidak dapat lagi digugat, tidak sesuai dengan ketentuan Pasal 14 Peraturan Menteri Agraria/Kepala Badan Pertanahan Nasional Nomor 9 Tahun 1999 yang tidak membatasi jangka waktu pihak-pihak lain yang merasa berkepentingan untuk menggugat hak atas tanah yang bersangkutan. Fakta-fakta yuridis inilah yang seharusnya dijadikan salah satu objek reformasi hukum pertanahan di Indonesia.

\section{Regulasi Hak atas Tanah Tidak lengkap}

Sebagaimana diketahui bahwa UUPA sebagai dasar pengaturan hak tanah hanya mengatur hal-hal yang bersifat pokok-pokok saja, sehingga beberapa ketentuan pelaksanaan diperintahkan untuk diatur kembali dengan peraturan 
perundang-undangan organik, baik berupa undang-undangan, peraturan pemerintah dan peraturan menteri. Dari sekian banyak yang diperintahkan UUPA untuk dibuatkan peraturan pelaksanaan, hanya sebagian saja yang dapat diwujudkan, masih banyak peraturan pelaksanaan yang seharusnya dibuat belum dapat direalisasikan, yaitu diantaranya pengaturan mengenai hak tanah sebagaimana yang disebut dalam Pasal 50 ayat (1) UUPA, yaitu mengenai pembentukan undangundang yang mengatur hak milik sampai dengan sekarang undang-undang tersebut belum dibentuk. Ketidaklengkapan pengaturan hak tanah tersebut diharapkan dapat segera dilengkapi dalam bentuk undang-undang hak tanah. Pengaturan hak milik yang semula diperintahkan dalam UUPA perlu dikembangkan menjadi pengaturan tentang hak tanah. Maksudnya adalah bahwa pada prinsipnya proses penguatan hak-hak individual yang sejalan dengan upaya menegakkan hak asasi manusia pada masa sekarang ini memerlukan antisipasinya. Berkenaan dengan perlakuan yang berbeda terhadap kesempatan mendapatkan hak milik atas tanah bagi perorangan (WNI) dengan badan hukum perlu dijelaskan sebagaimana yang diatur memori penjelasan umum UUPA II Nomor 5 yang menegaskan sebagai berikut :

"sesuai dengan asas kebangsaan tersebut dalam Pasal 1 maka menurut Pasal 9 jo Pasal 21 ayat (1) hanya warga negara Indonesia saja yang dapat mempunyai hak milik atas tanah. Hak milik kepada orang asing dilarang (Pasal 26 ayat (2). Orangorang asing dapat mempunyai tanah dengan hak pakai yang luasnya terbatas. Demikian pula pada dasarnya badan-badan hukum tidak dapat mempunyai hak milik (Pasal 21 ayat (2). Adapun pertimbangan untuk (pada dasarnya) melarang badan-badan hukum mempunyai hak milik atas tanah, ialah karena badan-badan hukum tidak perlu mempunyai hak milik tetapi cukup hak-hak lainnya, asal saja ada jaminan-jaminan yang cukup bagi keperluan-keperluannya yang khusus (hak guna usaha, hak guna bangunan, hak pakai menurut Pasal 28, 35 dan 41). Dengan demikian maka dapat dicegah usaha-usaha yang bermaksud menghindari ketentuan-ketentuan mengenai batas maksimum luas tanah yang dipunyai dengan hak milik (Pasal 17). Meskipun pada dasarnya badan-badan hukum tidak dapat mempunyai hak milik atas tanah, tetapi mengingat akan keperluan masyarakat yang sangat erat hubungannya dengan paham keagamaan, sosial dan hubungan perekonomian, maka diadakan suatu "escapeclouse" yang memungkinkan badanbadan hukum tertentu mempunyai hak milik. Dengan adanya "escapeclouse" ini maka cukuplah nanti bila ada keperluan akan hak milik bagi sesuatu atau sesuatu macam badan hukum diberikan dispensasi oleh pemerintah, dengan jalan menunjuk badan hukum tersebut sebagai badan hukum yang mempunyai hak milik atas tanah (Pasal 21 ayat (2). Badan-badan hukum yang bergerak dalam lapangan sosial dan keagamaan ditunjuk dalam Pasal 49 sebagai badan-badan yang dapat mempunyai hak milik atas tanah, tetapi sepanjang tanahnya diperlukan untuk usahanya dalam bidang sosial dan keagamaan itu. Dalam halhal yang tidak langsung berhubungan dengan bidang itu mereka dianggap sebagai badan hukum biasa." 
Namun lebih jauh menurut hemat Penulis perlakuan yang berbeda tersebut dapat dipahami karena: ${ }^{24} 1$. UUPA menganut prinsip nasionalitas sebagaimana yang diatur dalam Pasal 9 ayat (1) yang menyatakan bahwa hanya WNI yang dapat mempunyai hubungan yang sepenuhnya dengan bumi, air dan ruang angkasa dalam batas-batas ketentuan Pasal 1 dan 2 UUPA; 2. Suatu negara yang masih dalam pembangunan dan sebagian besar rakyatnya masih dalam keadaan miskin patut melindungi warganya supaya tanah-tanahnya tidak jatuh kepada yang bukan WNI; 3. Sebagai implementasi politik hukum agraria yang bertujuan mensejahterakan rakyatnya; dan 4. Memberikan kesempatan kepada rakyat (WNI) yang lebih luas untuk mengusahakan pemanfaatan tanah secara ekonomis dan optimal.

Lebih lanjut perbedaan pemberlakuan terhadap kepemilikan ini dapat dibenarkan karena negara (pemerintah) berwenang mengatur sebagaimana yang diatur dalam Pasal 2 ayat (2) UUPA sebagai berikut : a. Mengatur dan menyelenggarakan peruntukan, penggunaan, persediaan dan pemeliharaan bumi, air dan ruang angkasa tersebut; $b$. Menentukan dan mengatur hubungan-hubungan hukum antara orang-orang dengan bumi, air dan ruang angkasa; c. Menentukan dan mengatur hubungan-hubungan hukum antara orang-orang dan perbuatanperbuatan hukum yang mengenai bumi, air dan ruang angkasa.

Adanya kewenangan negara (pemerintah) menurut Pasal 2 ayat (2) UUPA di atas merupakan konsekuensi juridis atas eksistensi negara sebagai pemilik kedaulatan dalam rangka mensejahterakan rakyat (bonum publicum). Menurut penulis, asas menguasai negara adalah norma, selanjutnya "sejahtera" adalah tujuan untuk membahagiakan rakyat. Terpenting melalui hak menguasai negara, pemerintah dapat membuat instrumen peraturan perundang-undangan, sehingga terdapat akses rakyat terhadap pemilikan tanah dan mendatangkan kepastian hukum bagi rakyat dan investor dalam berinvestasi.

Banyak kasus pertanahan yang diakibatkan pada penerapan undang-undang yang sewenang-wenang untuk menghilangkan hak-hak kepemilikan individual, sebagai contoh implementasi Undang-Undang Nomor 26 Tahun 2007 tentang Penataan Ruang yang pada norma menghormati hak-hak kepemilikan individual, ternyata pada implementasinya dipergunakan sebagai alat (tool of government) untuk menindas, mematikan bahkan menghapuskan hak-hak individual. Untuk itu perlu

${ }^{24}$ Darwin Ginting, Kepemilikan Hak. Atas Tanah Bidang Agribisnis di Indonesia, Gahlia Indonesia, Jakarta, 2010, hlm. 112 
di pikirkan upaya menerbitkan undang-undang hak milik atau minimal undangundang hak atas tanah,kerena apabila tidak segera dibentuk maka akan menyebabkan timbulnya pluralisme hak milik.

\section{Kekosongan Hukum.}

Meningkatnya jumlah penduduk di beberapa kota besar, baik dikarenakan oleh pertumbuhan penduduk karena kelahiran maupun karena urbanisasi mengakibatkan kegiatan pembangunan semakin meningkat pula. Hal ini membawa konsekuensi diperlukannya persediaan tanah yang meningkat pula untuk menampung kegiatan pembangunan, baik untuk penyediaan tempat bermukim maupun kegiatan lainnya.

Banyak negara-negara eropa dan dunia, khususnya di area metropolitan mengalami kekurangan tanah kosong untuk menopang pembangunan. Para investor mencoba menggunakan dan memanfaatkan ruang di atas tanah dan di bawah tanah untuk pembangunan. Pada saat bersamaan penggunaan dan pemanfaatan ruang di atas dan di bawah tanah tersebut memerlukan ketelitian yang tinggi untuk mengadakan pendaftaran tanahnya, karena pendaftaran tanah tradisional tidak dirancang untuk hal yang demikian itu.

Akibat kebutuhan akan penyediaan tanah tersebut dan ditunjang oleh kemajuan teknologi, maka semakin memacu untuk memanfaatkan ruang yang ada baik di atas permukaan tanah maupun di bawah permukaan tanah. Fakta menunjukkan bahwa di beberapa kota besar di dunia, ruang di dalam tubuh bumi dan ruang udara di atas permukaan bumi sudah dimanfaatkan untuk menampung kegiatan penduduk antara lain dapat berupa usaha pertokoan, restoran, stasiun dan jalan kereta api bawah tanah dan lain-lain.

Menurut Pasal 4 ayat (1) UUPA yang dimaksud dengan "tanah" adalah permukaan bumi, sedangkan hak tanah adalah hak atas permukaan bumi, yaitu bagian tertentu dari permukaan bumi yang merupakan satuan yang terbatas dan berdimensi dua yaitu dengan ukuran panjang dan ukuran lebar tertentu. Karena sebidang tanah dikuasai dan dipunyai dengan tujuan untuk dipergunakan, tidak mungkin untuk digunakan apapun jika yang dipergunakan hanya permukaan bumi itu saja, maka oleh Pasal 4 ayat (2) UUPA, ruang penggunaannya diperluas. Perluasan ini meliputi ruang udara diatasnya dan sebagian tubuh bumi di bawah tanah yang bersangkutan. Akan tetapi yang diperluas adalah kewenangan untuk 
menggunakannya. Hal ini terbatas yaitu sekadar dipergunakan untuk kepentingan yang langsung berhubungan dengan penggunaan tanah (permukaan bumi) yang bersangkutan. Ruang udara dan tubuh bumi yang dipergunakan itu bukan hak pemegang hak tanah dan karenanya ia tidak berhak untuk menyerahkan penggunaannya kepada pihak lain, apabila tidak mengelola, berikut penggunaan permukaan buminya.

Sehubungan dengan reformasi hukum tanah di atas, apabila dikaitkan dengan investasi dalam sektor agribisnis, maka hal-hal yang menjadi substansi adalah reformasi dalam pemberian HGU. Kalau dilihat dari sisi jangka waktu sebagaimana yang diatur dalam UUPA yang hanya memberi jangka waktu 25 (dua puluh lima) tahun dan untuk perusahaan yang memerlukan waktu lebih lama dapat diberikan HGU paling lama 35 (tiga puluh lima) tahun, dan dapat diperpanjang paling lama 25 (dua puluh lima) tahun. Sehingga maksimal waktu yang dapat diperoleh dalam mendapatkan HGU adalah 35 + 25 = 60 tahun. Jangka waktu 60 (enam puluh) tahun HGU ini bagi agribisnis yang produksinya dapat dengan cepat seperti pisang, jagung, padi, ketela, dan sebagainya sama sekali tidak menimbulkan masalah bagi investor. Menjadi masalah apabila investor ingin menginvestasikan modalnya dalam bidang budi daya kehutanan atau tanaman keras, yang usia produksinya biasanya cukup lama, sehingga untuk mengejar tercapainya break event point cukup lama. Kondisi ini memerlukan pertimbangan yang matang, belum lagi kemungkinan hama dan resiko alam. Sebagai contoh kelapa sawit dan coklat perlu diberikan jangka waktu selama sembilan puluh sampai dengan seratus tahun dengan pertimbangan, bahwa tanaman keras ini tiap tiga puluh tahun harus dilakukan pemotongan pohon untuk peremajaan sehingga pemotongan sampai tiga kali dianggap sudah cukup ideal untuk berinvestasi di bidang agribisnis. ${ }^{25}$ Sedangkan luas minimum yang dianggap memenuhi syarat efisien dan ekonomis adalah sepuluh ribu hektar. Demikian juga dalam budidaya kayu ebony (kayu hitam) yang umur panennya mencapai 70 (tujuh puluh) sampai dengan 80 (delapan puluh) tahun. diketahui bahwa untuk dapat memanen sebatang (tegakan) kayu ebony apabila telah mencapai diameter (garis

${ }^{25}$ Tualar Simarmata, terhadap tanaman keras di bidang agrobisnis sudah sewajarnya diberikan jangka waktu Hak Guna Usaha yang cukup panjang, sehingga menyamai sebagaimana yang diatur dalam negara-negara lain, misalnya Thailand, Malaysia dan Vietnam. Karena untuk tanaman kelapa sawit setiap 30 (tigapuluh) tahun harus dilakukan pemotongan (peremajaan), sehingga dalam 3 (tiga) kali peremajaan diharapkan dibutuhkan jangka waktu 90 (sembilan puluh) sampai dengan 100 (seratus) tahun terhadap Hak Guna Usaha, sehingga diperkirakan cukup ideal untuk investasi di bidang agribisnis 
tengah) 1 (satu) meter, dan untuk mencapai diameter tersebut memerlukan waktu hidup selama 70 sampai 80 tahun.

Sehingga apa yang telah ditentukan dalam Undang-Undang Nomor 25 Tahun 2007 sudah tepat dari segi jangka waktu, hanya saja yang kurang tepat seharusnya khusus untuk tanaman agrobisnis karena resiko cukup tinggi maka perpanjangan jangka waktu itu tidak diperlukan evaluasi di tengah jalan karena hal ini sangat mengganggu kontinuitas produksi sehingga kepastian hukum untuk jangka waktu dapat menunjang ketenangan dan kenyamanan investor dibidang agribisnis. Hal ini sudah tepat bila dikaitkan dengan reformasi pemberihan Hak Guna Usaha dalam investasi pertanian modern dan komersial yang juga berlaku dinegara-negara tetangga kita misalnya negara Thailand dan Malaysia. Lompatan-lompatan luar biasa dalam investasi dan perekonomian global perlu dijadikan acuan dalam penentuan jangka waktu, oleh sebab itu untuk kondisi sekarang, keberadaan UUPA yang mengatur mengenai HGU telah ketinggalan zaman. Memang hukum selalu tertatihtatih mengikuti perkembangan masyarakat. Di sinilah perlunya peranan hukum sebagai sarana pembaharuan pola pikir pemerintah dan masyarakat yang kebutuhannya berkembang sesuai dengan tuntutan perkembangan ekonomi, teknologi dan globalisasi.

Jelasnya bahwa untuk mendorong investasi agrobisnis, maka perlu dilakukan pembaharuan hukum tanah dan aspek pendukung lainnya,sebagai berikut;adanya : (a) Kepastian hukum di bidang pertanahan, (b) penambahan jangka waktu yang lebih lama dalam pemberian HGU; (c) birokrasi perizinan yang efisien, seperti misalnya sistem perizinan satu pintu; (d) kesiapan infrastruktur, seperti jalan, jembatan, pelabuhan laut dan udara yang dapat memberikan kemudahan transportasi untuk mengakses lahan-lahan yang tepat untuk investasi agrobisnis; (e) keamanan dan penegakan hukum yang bermuara pada iklim investasi yang kondusif; (f) adanya insentif pajak dari pemerintah terhadap PMA yang menginvestasikan modalnya pada sektor agrobisnis.

\section{Penutup}

Berdasarkan paparan yang dikemukakan di atas, maka dapat ditawarkan format kebijakan hukum masa depan yang mengungkap perlindungan hak atas tanah perorangan dan penanaman modal bidang agrobisnis sebagai berikut. Pertama, perlu segera 
dilakukan pembentukan rancangan undang-undang hak atas tanah, sehingga dapat menunjang kepastian hak atas tanah bagi perorangan dan kepastian hukum bagi setiap sektor penanaman modal, lebih khususnya bidang agrobisnis. Kedua, pembentukan perundang-undangan tersebut mengedepankan aspirasi masyarakat dan masyarakat industri bidang agrobisnis dan selanjutnya ditetapkan melalui lembaga yang berwenang dalam bentuk undang-undang, sehingga dapat menunjang perkembangan perekonomian nasional dan dapat bersaing dengan memperhatikan kebutuhan masyarakat dan kebutuhan jangka waktu hak atas tanah dalam bidang agrobisnis, khususnya tanaman keras.

\section{Daftar Pustaka}

Arifin, Winarsih \& Farida Soemargono, Kamus Prancis Indonesia; Dictionnaaire Francais - Indonesien, Gramedia Pustaka Utama, Jakarta, 2007.

Ginting, Darwin, Kepastian Hukum Kepemilikan Hak Atas Tanah Bidang Agribisnis di Indonesia, Unpad Press, Bandung, 2009.

, Kepemilikan Hak Atas Tanah Bidang Agribisnis di Indonesia, Gahlia Indonesia, Jakarta, 2010.

Guindel, Milagros, Kamus Spanyol Indonesia, Gramedia Pustaka Utama, Jakarta, 2001.

Harsono, Budi, Reformasi Hukum Tanah Yang Berpihak Kepada Rakyat, Mandar Maju, Bandung, 1991.

I., Syaukani \& Thohari A.A, Dasar-dasar Politik Hukum. Raja Grafindo Persada, Jakarta, 2004.

L., Rasjidi \& I.B.W Putra, Hukum sebagai suatu sistem. Mandar Maju, Bandung, 2003.

Lewi, Michael, Teologi Pembebasan, Insist Press bekerjasama dengan Pustaka Pelajar, Cet.II, Yogyakarta, 2000.

M. Echols, John \& Hasan Sadily, Kamus Inggris - Indonesia; An English - Indonesian Dictionary, Cornell University Press - Gramedia, Itacha and London Jakarta,1995.

M., Kusumaatmadja, Konsep-konsep hukum dalam pembangunan. Pusat Studi Wawasan Nusantara, Hukum dan Pembangunan Bekerjasama dengan Alumni, Bandung, 2002.

Moeiman, Susi \& Hein Steinhauer, Kamus Belanda - Indonesia, Gramedia Pustaka Utama, Jakarta, 2008.

Rasjidi, Lili, Filsafat Hukum; Apakah Hukum itu?, Remaja Rosdakarya, Bandung, 1993. \& Ira Thania Rasjidi, Pengantar Filsafat Hukum, Mandar Maju, Bandung, 2002. 
Shidarta, Karakteristik Penalaran Hukum Dalam Konteks Keindonesiaan, CV. Utomo, Bandung, 2006

Suparji, Penanaman Modal Asing di Indonesia, Insentif V. Pembatasan, Jakarta, Universitas Al-Azhar Indonesia, tahun 2008,

Winoto, Joyo, Reformasi Agraria Dan Keadilan Sosial, Bandung, Pidato Ilmiah yang disampaikan dalam rangakaian Dies Natalis Universitas Padjajaran ke 50 tanggal 10 September 2007.

Undang-Undang Dasar Tahun 1945

Undang-Undang Pokok Agraria Nomor 5 Tahun 1960, tentang Peraturan Dasar Pokok-pokok Agraria.

Undang-Undang Nomor 25 Tahun 2007 tentang Penanaman Modal.

Undang-Undang Nomor 26 Tahun 2007 tentang Penataan Ruang.

Ketetapan Majelis Permusyawaratan Rakyat Nomor IX Tahun 2001 tentang Pembaharuan Agraria dan Pengelolaan Sumber daya Alam.

Keputusan Presiden Nomor 34 Tahun 2003 tentang Kebijakan Nasional di Bidang Pertanahan. 